\title{
FUZZY MODEL USED FOR THE PREDICTION OF A STATE OF EMERGENCY FOR A RIVER BASIN IN THE CASE OF A FLASH FLOOD - PART 2
}

\author{
${ }^{1,2)}$ PETR JANÁL, ${ }^{2)}$ MILOŠ STARÝ \\ ${ }^{1)}$ Czech Hydrometeorological Institute, Brno Regional Office, Kroftova 43, 616 67, Brno, Czech Republic; \\ Mailto: petr.janal@chmi.cz \\ ${ }^{2)}$ Brno University of Technology, Faculty of Civil Engineering, Institute of Landscape Water Management, Žižkova 17, \\ 66237 Brno, Czech Republic; Mailto: stary.m@ffce.vutbr.cz
}

This article is a continuation of a previous one named Fuzzy model use for prediction of the state of emergency of river basin in the case of flash flood (Janál \& Starý, 2009), where the potential applications of fuzzy logic in the field of flash flood forecasting were described. Flash flood forecasting needs a specific approach because of the character of torrential rainfall. Storms are very difficult to forecast in space and time. The hydrological models designed for flash flood prediction have to be able to work with very uncertain input data. Moreover, the models have to be capable of evaluating the level of danger in as short a time as possible because of the highly dynamic character of the modeled process. The fuzzy model described in the previous article was modified into a form usable in operational hydrology and a simulation of its operational application was run using this model. The selected time period for the simulation was the summer of 2009, when numerous flash floods occurred in Czech Republic. The topic of this article is the preparation of the model for practical use and the results of the simulation of its operation.

KEY WORDS: Fuzzy Logic, Fuzzy Sets, Small River Basin, Operational Prediction.

Petr Janál, Miloš Starý: FUZZY MODEL PRO P̌̌EDPOVĚĎ STUPNĚ OHROŽENOSTI POVODÍ POVODNĚMI Z PŘÍVALOVÝCH DEŠŤU゚ - 2. ČÁST. J. Hydrol. Hydromech., 60, 2012, 3; 9 lit., 11 obr.

Článek navazuje na předchozí článek s názvem Fuzzy model pro předpověd' stupně ohroženosti povodí povodněmi z přivalových dešt’o (Janál, Starý, 2009a). V úvodním článku byly popsány možnosti využití fuzzy logiky v problematice operativních předpovědí povodní způsobených prrívalovými srážkami. Předpověd' tohoto druhu povodní vyžaduje specifický přistup, jelikož výskyt přivalových srážek v prostoru a čase lze, díky jejich charakteru, jen stěží předpovídat. Hydrologické modely, určené pro předpověd' povodní jimi způsobenými musí být schopny pracovat s velmi neurčitými vstupy. Díky vysoké dynamice předpovídaného procesu musí být navíc schopny vyhodnotit vstupní data ve velmi krátkém čase. Fuzzy model, popsaný v prvním díle, byl upraven do podoby využitelné v operativní hydrologii a byl otestován pomocí simulace operativního provozu ve zvoleném období z léta 2009, kdy byla ČR zasažena četnými povodněmi z přivalových srážek. Úpravy modelu pro praktické využití a vyhodnocení zpětné simulace jeho provozu jsou předmětem předloženého navazujícího článku.

KLÍČOVÁ SLOVA: fuzzy logika, fuzzy množiny, malá povodí, operativní předpověd'.

\section{Introduction}

The previous article deals with fuzzy model configuration and calibration. As a brief reminder: the model estimates incoming peak flow on the basis of inputs characterizing an affected river basin (area, basin shape coefficient, forest cover, falling gradient) and inputs characterizing causal rainfall (average intensity and duration of rain, antecedent precipitation index). The fuzzy model is configured on the basis of what is termed a pattern matrix. The pattern matrix assigns output quantity values to certain combinations of input quantity values. In this way the matrix maps out the behavior of the modeled system in certain situations. On the basis of the learned information, the fuzzy model is also capable of providing output variable values for unknown situations. In other words, the fuzzy model enables the approximation of relations in a multidimensional space of input-output variables. In order to configure the pattern matrix it is necessary to process the input-output relations for flood 
events which occurred in the past; a set of what are termed sample river basins is used for this purpose. At the beginning of solving the task the derived data were used for pattern matrix configuration. The values of input variables characterizing causal rainfall (average intensity and duration of rain) and the antecedent saturation of the affected basin (antecedent precipitation index) and appropriate output variable values (peak flow) were derived through the use of basic hydrological formulas. The pattern matrix configured in this way was utilised in the development of methods of fuzzy model configuration and calibration, as described in the previous article. In the sequel to that article, i.e. the current paper, information is given regarding the testing of such a model for operational application. This model must be derived from a high-quality pattern matrix based on measured data from real flood events. Meteorological radar measurements and hydrological gauging stations are the data sources for that pattern matrix (involving cooperation with the Czech Hydrometeorological Institute, Brno and Ostrava Regional Offices). The fuzzy model dealt with in this article is specifically used in connection with precipitation nowcasting (short-term forecasting, i.e. usually up to three hours in advance). Model testing was performed via the retroactive simulation of model operation. The Czech Republic was affected by numerous flash floods during the summer of 2009, which is why this period was selected for the simulation. The article describes the procedure of operational input data acquisition, the retroactive simulation of model operation itself, prob- lems that appeared during the simulation, and their solutions. The results are illustrated by several examples and a general evaluation is included.

\section{Methodology}

The model is conceived as being able to evaluate current data gained from meteorological radar measurements. Every 5 minutes, the model analyzes current precipitation data (measured and forecast) for the chosen set of small river basins. The time step is determined by the intervals at which the meteorological radar measurements are made. It is necessary to determine the values of model input variables for each time step. The inputs characterizing basin morphology are constant over time and are determined beforehand. Time-varying variables (average intensity of rain, duration of rain, antecedent precipitation index) have to be determined for each time step.

Meteorological radar measurements provide measured immediate average precipitation intensities within the areas of the chosen basins as well as forecasts of these intensities up to 3 hours ahead. They also provide precipitation totals for the chosen basin areas at chosen time intervals. The aforementioned data have to be processed in order that they correspond with the fuzzy model's input data format. This means that the average intensity of rain, duration of rain and antecedent precipitation index have to be determined. Calculation of the average intensity and duration of rainfall during operation of the model is illustrated in Fig.1.

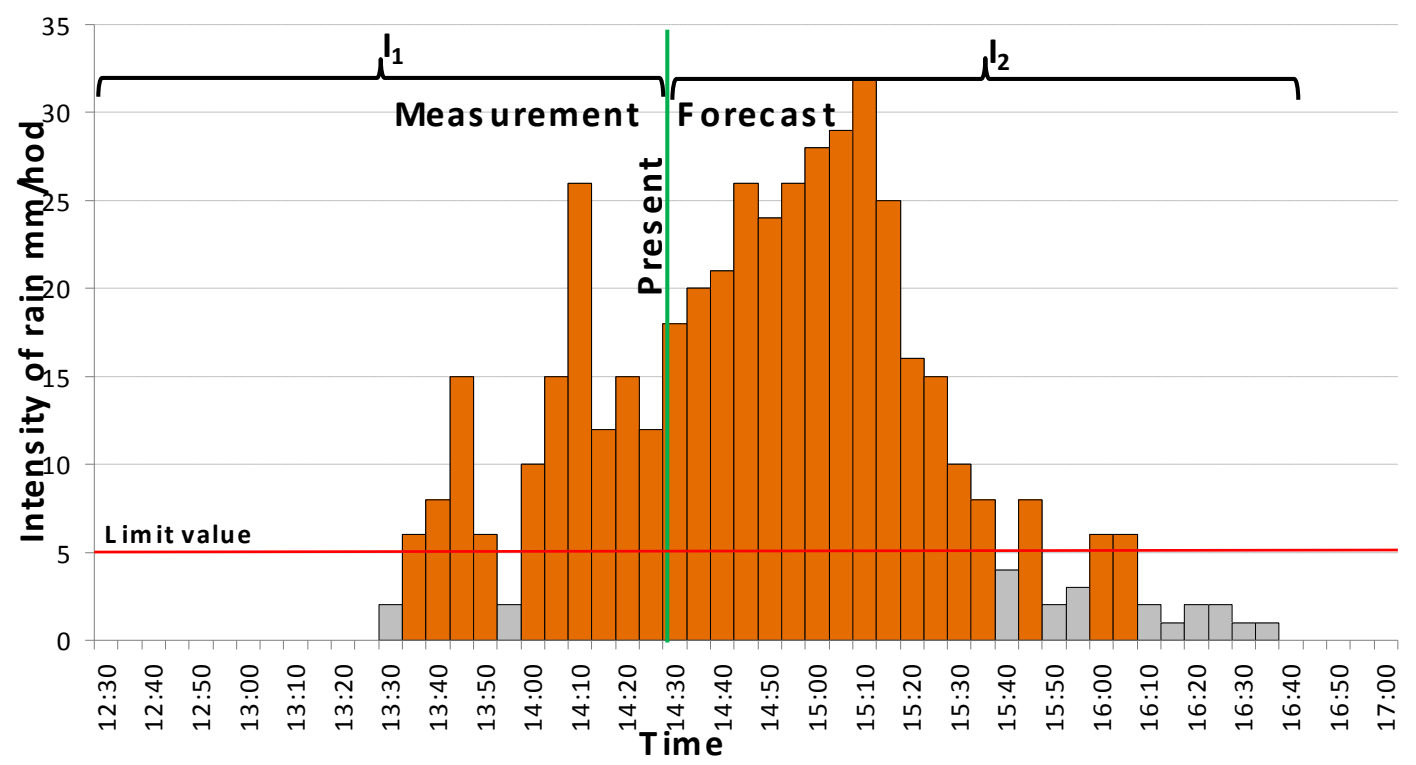

Fig. 1. Calculation of the average intensity and duration of rainfall during model operation. 
A certain time interval $I$ is considered in each calculation time step. Time interval $I$ is composed of time intervals $I_{1}$ and $I_{2}$, see Fig. 1. Time interval $I_{1}$ represents the time preceding the time considered as 'now' in the simulation. The rainfall intensity values contained in time interval $I_{1}$ are directly obtained from meteorological radar measurements. Time interval $I_{2}$ is determined by the length of the precipitation forecast (nowcast) being considered The rainfall intensity values contained in time interval $I_{2}$ are gained via extrapolation from meteorological radar measurements. The sizes of these intervals were derived from the operational testing of the model. It is necessary to be aware of the fact that the success rate of forecasts decreases with increasing nowcasting length.

The considered time interval $I$ is fixed for each calculation time step no matter whether the total rainfall is included within interval $I$ or not. Only intensity values exceeding or at least achieving the selected limit are considered within interval $I$. Today, the limit value is set to $5 \mathrm{~mm} \mathrm{~h}^{-1}$ (on the basis of practical experience). The same limit value was applied during configuration of the pattern matrix. A shift in the limit value requires the reconfiguration of the pattern matrix and recalibration of the model. The input value of average rainfall intensity is obtained as an average of the considered intensity values. The input value of rainfall duration is obtained from the time step multiplied by the number of considered intensity values. Also, the process of obtaining input variable values has to be taken into account during the interpretation of model outputs. It's necessary to realize that the rainfall enters the considered time interval $I$ gradually until it is totally included in the interval. Then, the rainfall exits the considered time interval $I$ gradually. Cases when two or more rainfalls pass over the basin area one after another also can occur. In these situations it is possible that the time interval in question may contain part of the outgoing rainfall and part of the incoming precipitation. The model always considers the rainfall as a whole within the frame of the considered time interval $I$.

The task of obtaining the antecedent precipitation index value remains. This value is calculated from the daily precipitation totals within the given basin.

Retroactive simulation of model operation was carried out in two ways. In the first case the precipitation forecast was replaced by measured values. This is an ideal scenario in which it is assumed that the precipitation forecast has the same accuracy as the measurements. In the second case the operation of the model in real time was simulated and only data which would be obtainable in real time were used.

When the model was provided with operational data it became apparent that in the case of some modeled basins the output values of the model were outside the range of peak flow values which are common for the given basin. This problem can be caused by several factors:

- The model is tailored to flood event peak flow forecasting. The capacity to express the basin's reaction to low precipitation is not included in the pattern matrix used to train the model.

- The set of modeled basins is spread out over a relatively extensive area. A single model is used for rainfall-runoff process simulation within e.g. a basin lying in South Moravia and a basin lying in the Jeseníky Mountains.

- A peak flow value is gained simply by multiplying a specific peak flow by a given basin area (see the previous article).

- Inputs characterizing basin morphology do not necessarily accurately represent the real conditions in a single basin.

- Peak flow size is affected by a lot of factors. The selected inputs to the model cover only the most important of them.

It became apparent that there is a need for the additional clustering of modeled basins. Another input (Basin type) was integrated into the model. The new input covers the influence of factors not covered by the original inputs. This input was placed at the end of the sequence of fuzzy inference systems (FIS) with the aid of another FIS. A schematic diagram of the resulting fuzzy model is depicted in Fig. 2, where $\tau$ means duration of rain, $i-$ average intensity of rain, $A P I$ - antecedent precipitation index, $\alpha$ - basin shape coefficient, $F G$ - falling gradient, $F C$ - forest cover, $A$ - area of basin, $q_{1, \ldots, 6}-$ estimates of specific peak flow and $Q$ means resulting estimate of peak flow. The resulting model is created by a sequence of six interconnected FIS. The specific peak flow is the output variable of a single FIS. At the end of the sequence the specific peak flow is multiplied by the area of a given basin. In this way the resulting peak flow is gained. The course of the computation through the sequence of FIS and the reasons for the sequential adding of inputs is described in the previous article. 


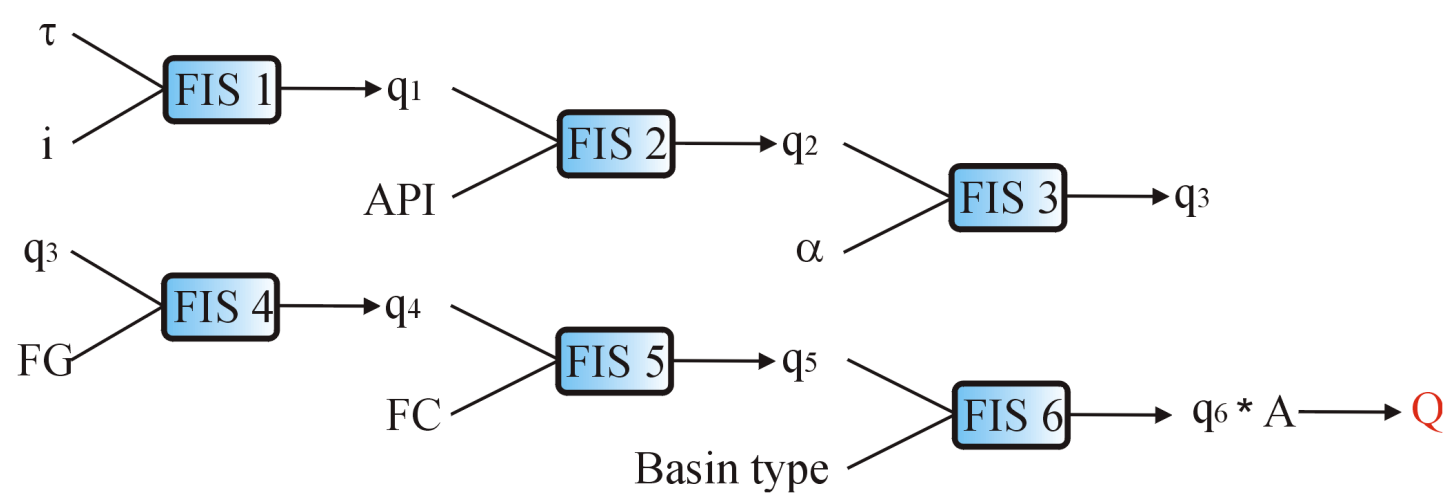

Fig. 2 Schematic diagram of the fuzzy model.

The values of the output variable Basin type can be integral numbers which determine the membership of a given basin within a certain class. The values of the variable Basin type were set for each modeled basin via the method detailed below.

The first step was the investigation of how the model works for single basins without using the input variable Basin type. Universes (domains of definition) of variables $\tau, i$ and $A P I$ were divided into certain regular steps. Variable $\tau$ was divided using 5 minute steps; variable $i$ in steps of $1 \mathrm{~mm} \mathrm{~h}^{-1}$; and, in the case of variable $A P I, 5 \mathrm{~mm}$ steps were used. All of the possible combinations were created for the gained values of variables $\tau, i$ and API. In this way a grid mapping the space of these three variables was obtained, partitioned according to the given sizes of the chosen steps. This grid served as the input data set (the remaining input variables characterizing basin morphology are constant for single modeled basins) for each basin. After calculation of the fuzzy model (using the gained input data set), maximum and minimum estimated output variables (peak flow) were determined for each basin. The intervals in which peak flows were estimated to occur were compared with the intervals in which the real peak flows of the given basins occur. For this purpose, $N$-year flood discharges were determined for each modeled basin (in profiles where $\mathrm{N}$-year discharges were not available, the method of analogy was applied). Peak flows ranging between the 0.5 and 100 year discharge value were selected for the intervals in which flood peak flows occurred in real life. It is assumed that if the model forecasts only a 100-year peak flow and the real peak flow is higher, the forecast can be still classified as successful. Basins with a similar hydrological reaction to precipitation were found through the comparison of ranges of modeled and real peak flows. The basins were then divided into classes. In this way, values were gained for the variable Basin type.

\section{Application}

The resulting fuzzy model is derived from a pattern matrix based on measured data from the period 2004-2007. Flood events which occurred during this period within the set of selected basins were evaluated using data from meteorological radar and from gauging stations.

The model was verified through retroactive simulation of its operation during the period 24. 6 . - 17. 7. 2009 when the Czech Republic was affected by numerous flash floods. A set of 90 basins were modeled (Fig. 3). Most of the modeled basins contain gauging stations, enabling the evaluation of forecast success and the obtaining of new patterns for model calibration. Mainly the northern and northeastern parts of Moravia were affected by flash floods during the simulation period.

The time intervals $I_{1}$ and $I_{2}$ (Fig. 1) were set in the following way. Time interval $I_{1}$ (time previous to the time considered as 'now' in the simulation) was set at 2 hours. Time interval $I_{2}$, which included the considered precipitation forecast length, was selected as 3 hours. The calculation was also processed using a shorter time interval $I_{2}$ (1 hour), but not for all basins. In cases when interval $I_{2}$ was shorter, interval $I_{1}$ was prolonged to 4 hours so that the total interval $I$ was unchanged.

The values of the inputs characterizing causal rainfall change over time according to changes in the precipitation forecast and as the considered time interval I shifts. However, this does not constitute continuous modeling. Within each time step (5 minutes) the model evaluates the situation based on updated input data. There is no connection with the calculation in the previous step. 


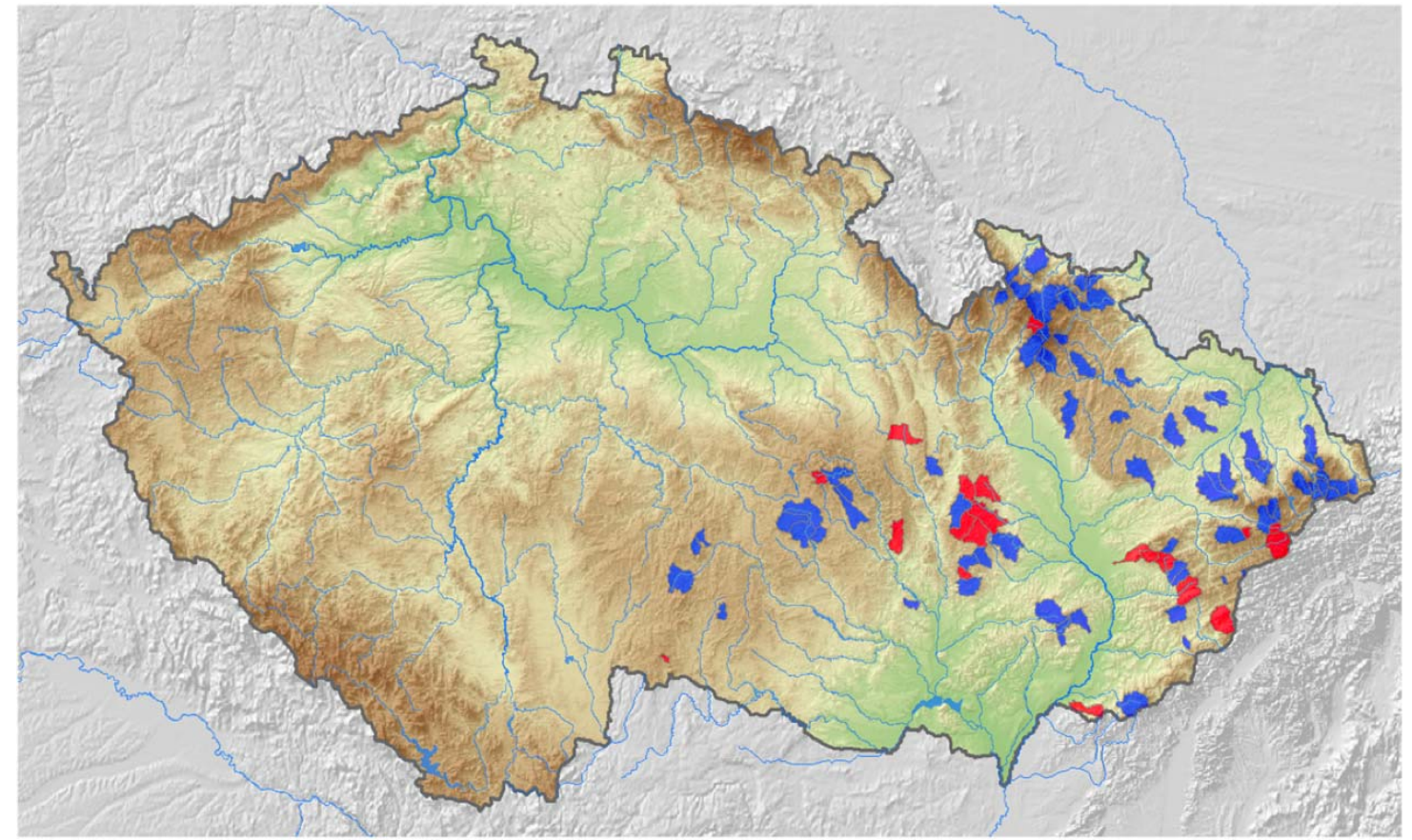

Fig. 3. The set of pattern river basins (red) and basins used for operational simulation (red and blue).

Fuzzy model forecast data were only evaluated for 73 of the 90 modeled basins because hydrological data was missing for 17 of the basins. The results for two of the basins (the Velička and Fryšávka River basins) are presented in this article. They are used to illustrate different aspects of forecasting.

On the following graphs the forecasted incoming peak flows are displayed as triangles and are assigned to the time when the forecast was released. The fuzzy model doesn't determine the time when the peak flow occurs; the triangles are not meant to follow the course of measured discharges at a gauging station but rather to estimate the height of the peak flow which is a threat in the near future. Furthermore, the measured hourly average discharges, measured peak flows and actual $N$-year discharges for the studied basins are also presented on the graphs. The measured course of average precipitation intensities is shown on the upper horizontal axis.

Velička river basin was affected by flooding late at night on 24. 6. 2009. At the Hranice gauging station the peak flow reached $50 \mathrm{~m}^{3} \mathrm{~s}^{-1}$; this means that the basin's 50-year flood discharge value was almost reached. Peak flow estimates during the simulated period are shown in Fig. 4. Precipitation nowcasting was replaced by measured values in this case. This constitutes an ideal scenario when the precipitation forecast is supposed to have the same accuracy as real measurements. Future peak flow estimates based on 3 hour precipitation nowcasting can be found in Fig. 5. (orange triangles). It is evident that the result of hydrological forecasting significantly depends on the success of meteorological forecasts.

The lead time of forecasts before the event of flooding is clear from the detailed view of the flood event that took place on the night of 24. 6. (Fig. 6). In the case when precipitation nowcasting is replaced by measured values the model estimated a future peak flow of around the 10-year flood discharge value even before the flood arrived (at approx. $5 \mathrm{PM}$ ). After $6 \mathrm{PM}$ the model forecasted the imminent exceeding of the 20-year discharge value. Using precipitation data obtainable in real time, the situation is different. In real time operation, the first warning would be obtained at the time when the flood is already in progress. Despite this, the forecast would be usable in practice.

The fact that peak flow estimates decline after approx. $9 \mathrm{PM}$ is due to the movement of the causal rainfall out of the considered 5 hour interval (2 hours previous, 3 hours later). Although the presentation of the model's outputs can give the impression that it is modeling the hydrograph, that is not the case. The fuzzy model is merely refining the estimates of future peak flow over the course of time depending on the updating of input data. 


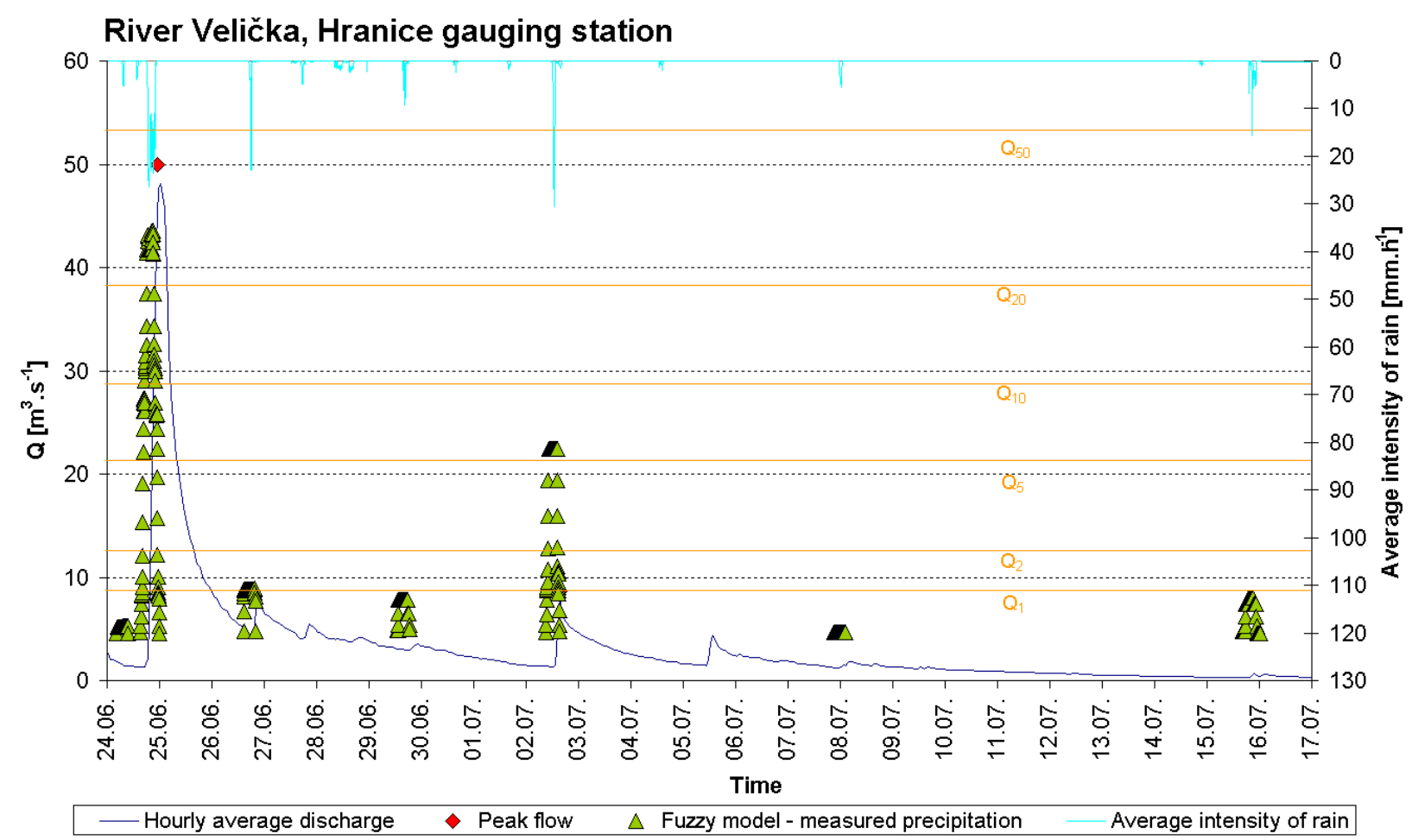

Fig. 4. Peak flow estimates - Velička River basin - measured precipitation used instead of nowcasting.

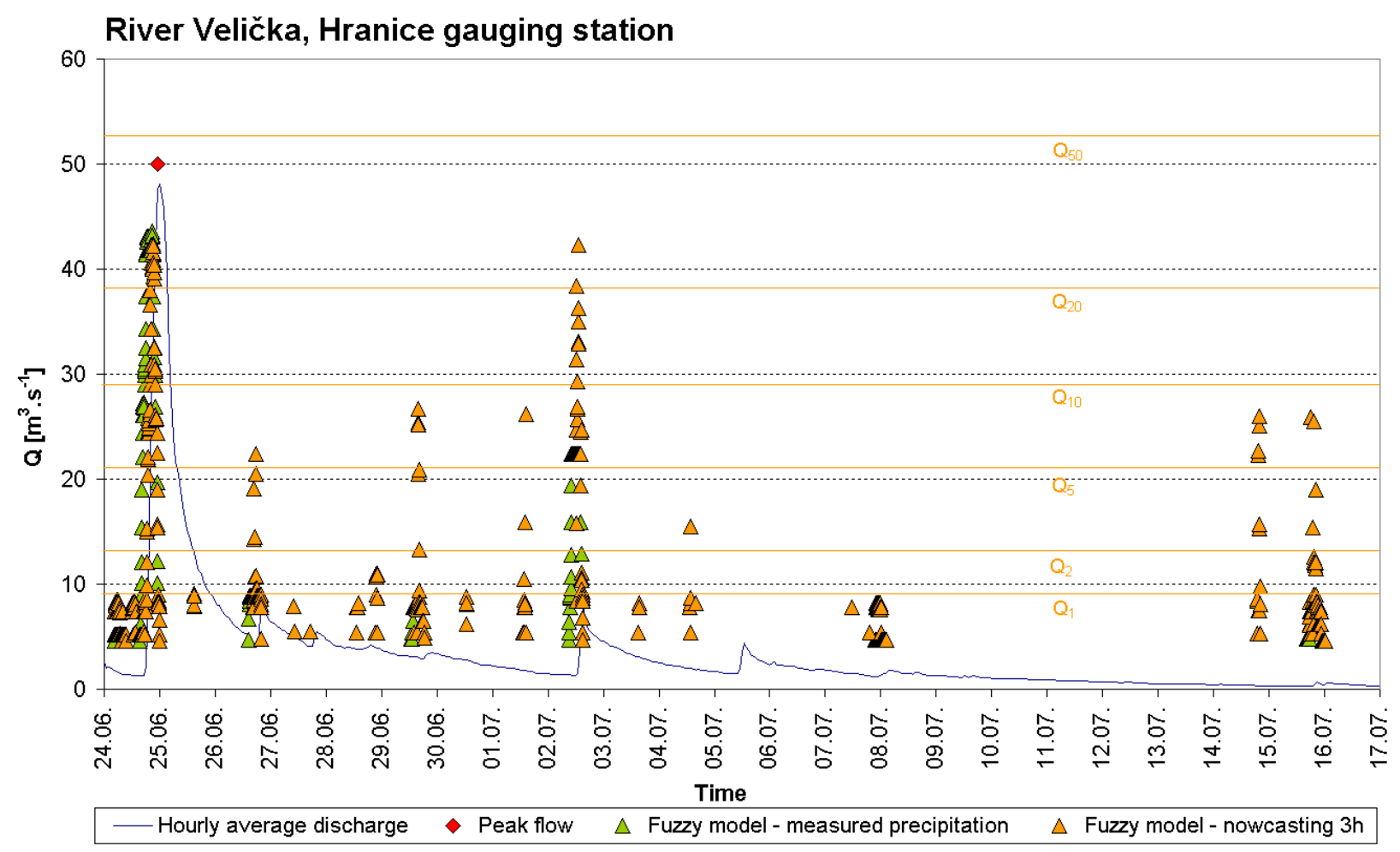

Fig. 5. Peak flow estimates - Velička River basin - comparison of results based on measured precipitation only and results based on precipitation nowcasting (3h). 


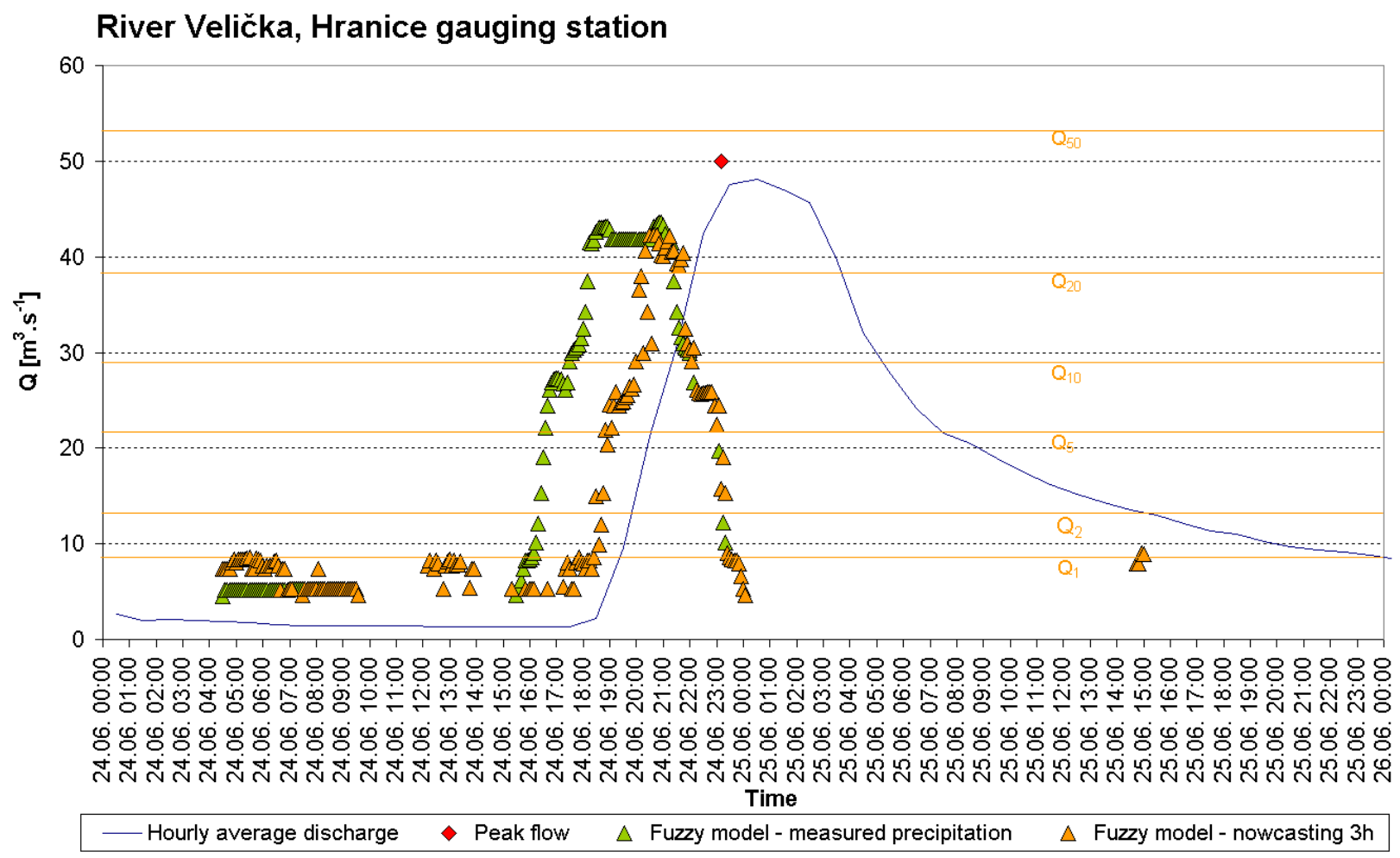

Fig. 6. Peak flow estimates - Velička River basin - comparison of results based on measured precipitation only and results based on precipitation nowcasting (3h) - the flood event of 24-25. 6. 2009.

The nowcasting of precipitation for such a long period into the future as is considered here - three hours - results in an increase in the number of false alarms. The shortening of nowcasting validity time eliminates these false alarms to a certain extent; however, the maximum possible lead time of the peak flow forecast is reduced. How this occurs is clear in the detailed comparison of peak flow estimates for the afore-mentioned flood in the Velička river basin with the two considered precipitation nowcasting validity times in Fig. 7; the shortening of the peak flow forecast lead time didn't prove to be significant in the case of that flood event.

The positive influence of shorter precipitation nowcasting validity on the number of false alarms is obvious from the depiction of forecast results during the whole simulation period (Fig. 8).

The results of the simulation of model operation for the Fryšávka River basin are presented here as another example. In this case, the peak flow reached the 20-year flood discharge value (on 25. 6 . 2009 at 19:30). Peak flow estimates during the whole simulated period are presented again (Figs. 10 and 11). Forecasts obtained using the measured data instead of precipitation nowcasting are presented in Fig. 9. The forecasts shown in Fig. 10 were derived from data which would have been obtainable in real time.

The lead time of the peak flow forecast is approx. 3 hours before the flood arrives in the ideal scenario where measured values are used instead of precipitation nowcasting (Fig. 11). In real time, the warning would actually come at the time when the flood arrives. Based on forecasted precipitation, the model forecasted a peak flow of between the 10 and 20 year flood discharge values approx. 1 hour before the 2-year discharge value was reached at Kadov gauging station.

A general evaluation of the simulation of model operation was performed via the following method. Only flood events with a peak flow exceeding the 2-year flood discharge value were included in the general evaluation of results. Forecasts of discharges of less than $Q_{2}$ were considered as unimportant. With regard to the selected flood events the situations when the model forecasted peak flows exceeding the 2-year discharge limit were considered as successful forecasts. In the cases when the model's estimates did not exceed $Q_{2}$ during some of the selected flood events the forecast was considered as having failed. Situations when the exceeding of $Q_{2}$ was forecasted but did not happen were considered as false alarms. Forecasted precipitation intensity 


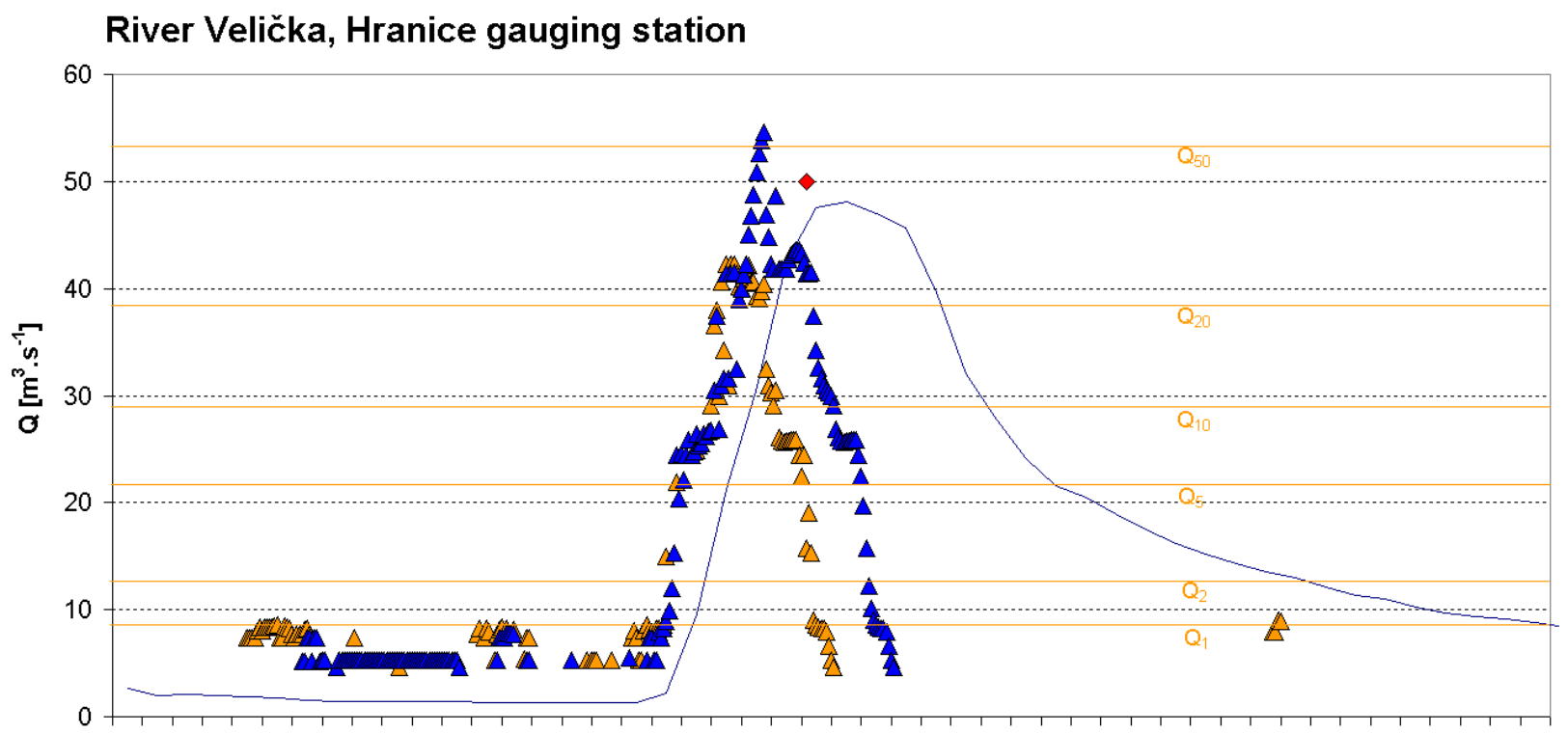

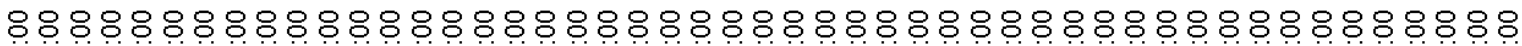

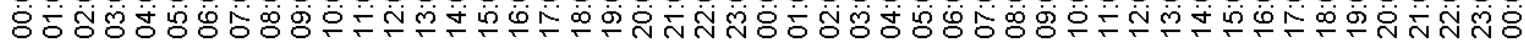

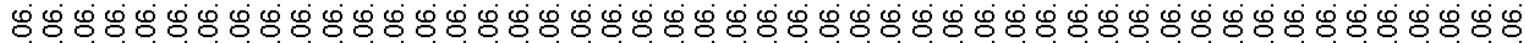

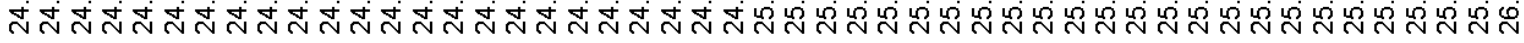

Time

Hourly average discharge $\diamond$ Peak flow $\triangle$ Fuzzy model-nowcasting $3 \mathrm{~h}$

A Fuzzy model-nowcasting $1 \mathrm{~h}$

Fig. 7. Peak flow estimates - Velička River basin - comparison of results based on 1 hour and 3 hour precipitation nowcasting - the flood event of 24-25. 6. 2009.

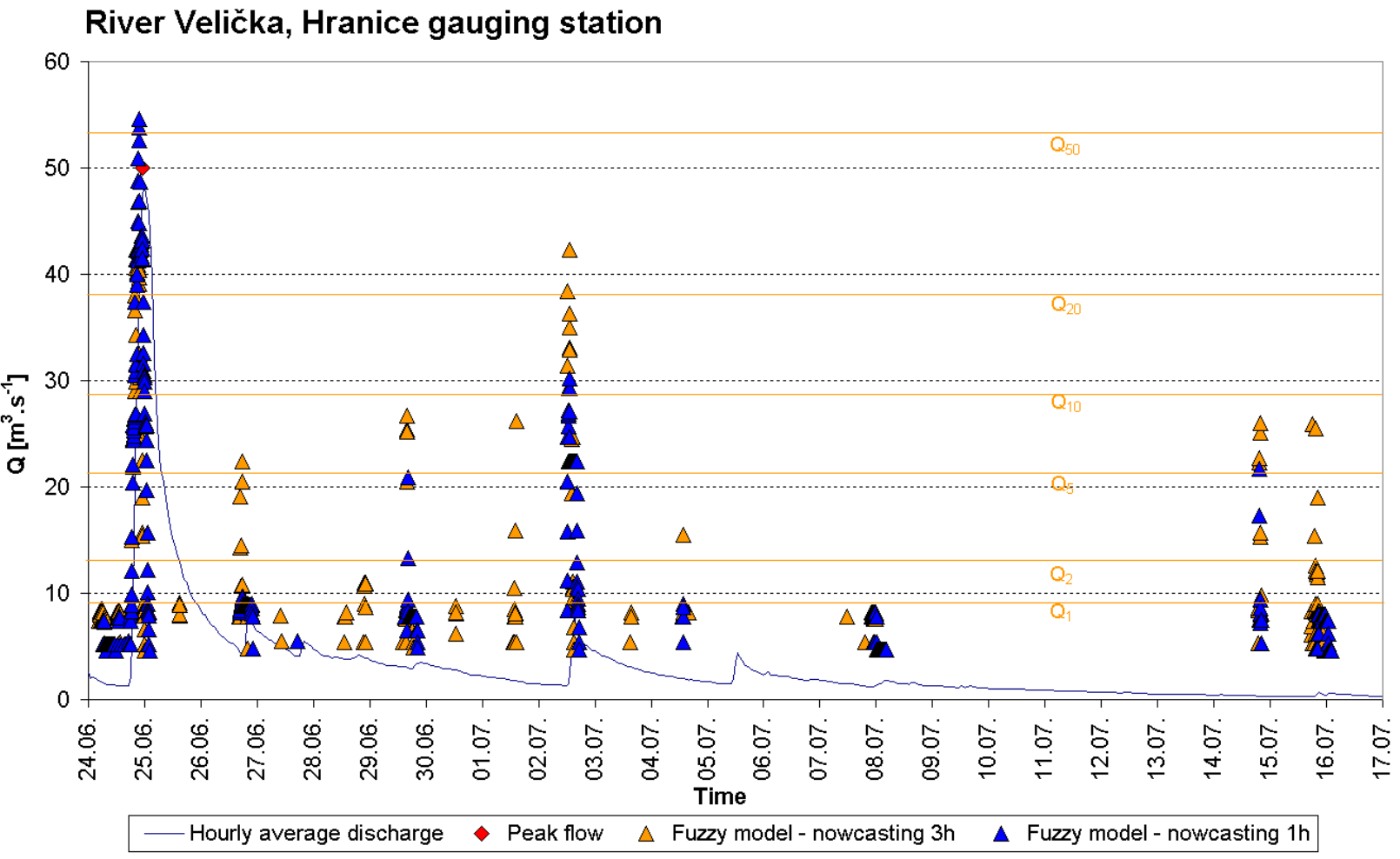

Fig. 8. Peak flow estimates - Velička River basin - comparison of results based on 1 hour and 3 hour precipitation nowcasting. 


\section{River Fryšávka, Kadov gauging station}

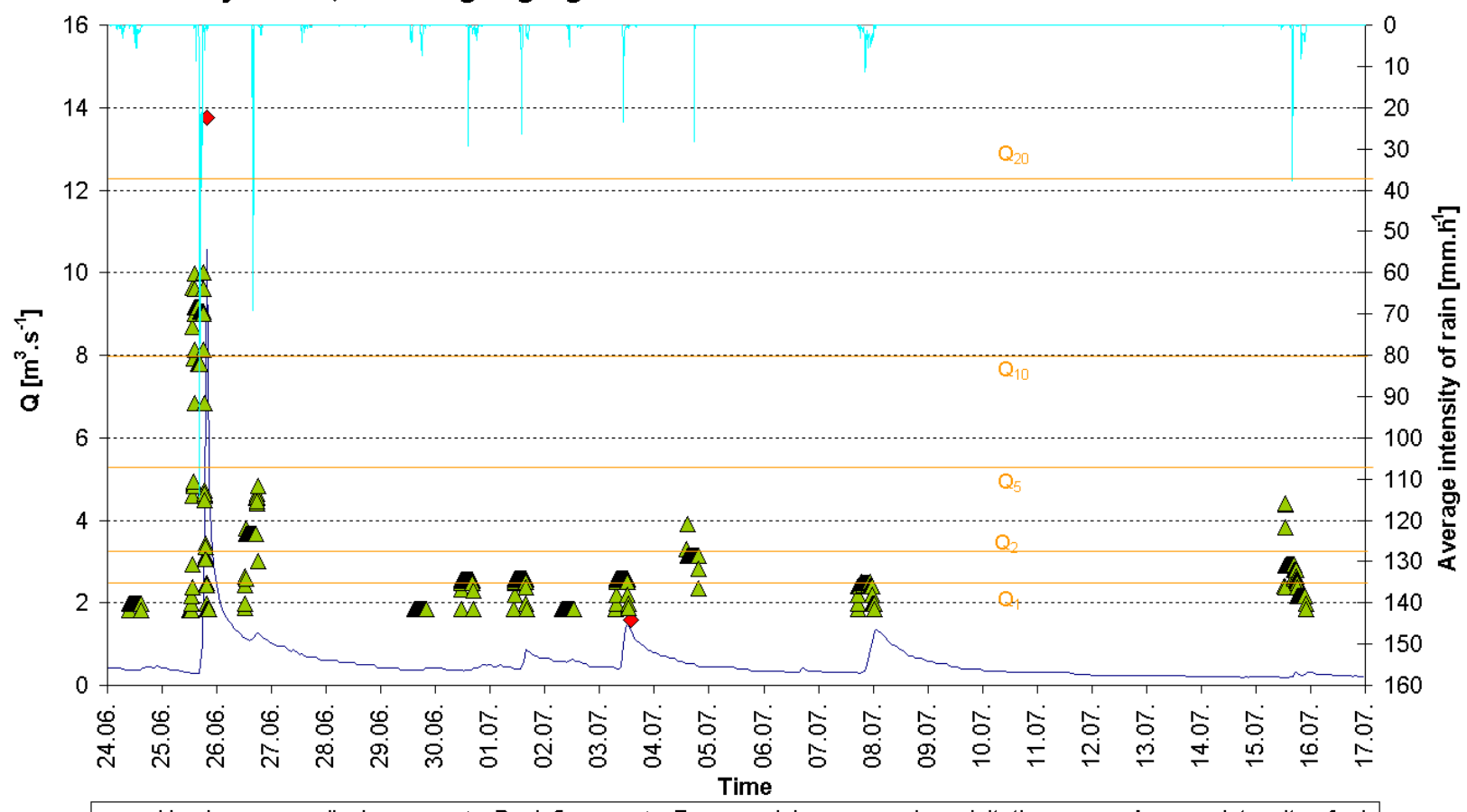

Fig. 9. Peak flow estimates - Fryšávka River basin - measured precipitation used instead of nowcasting.

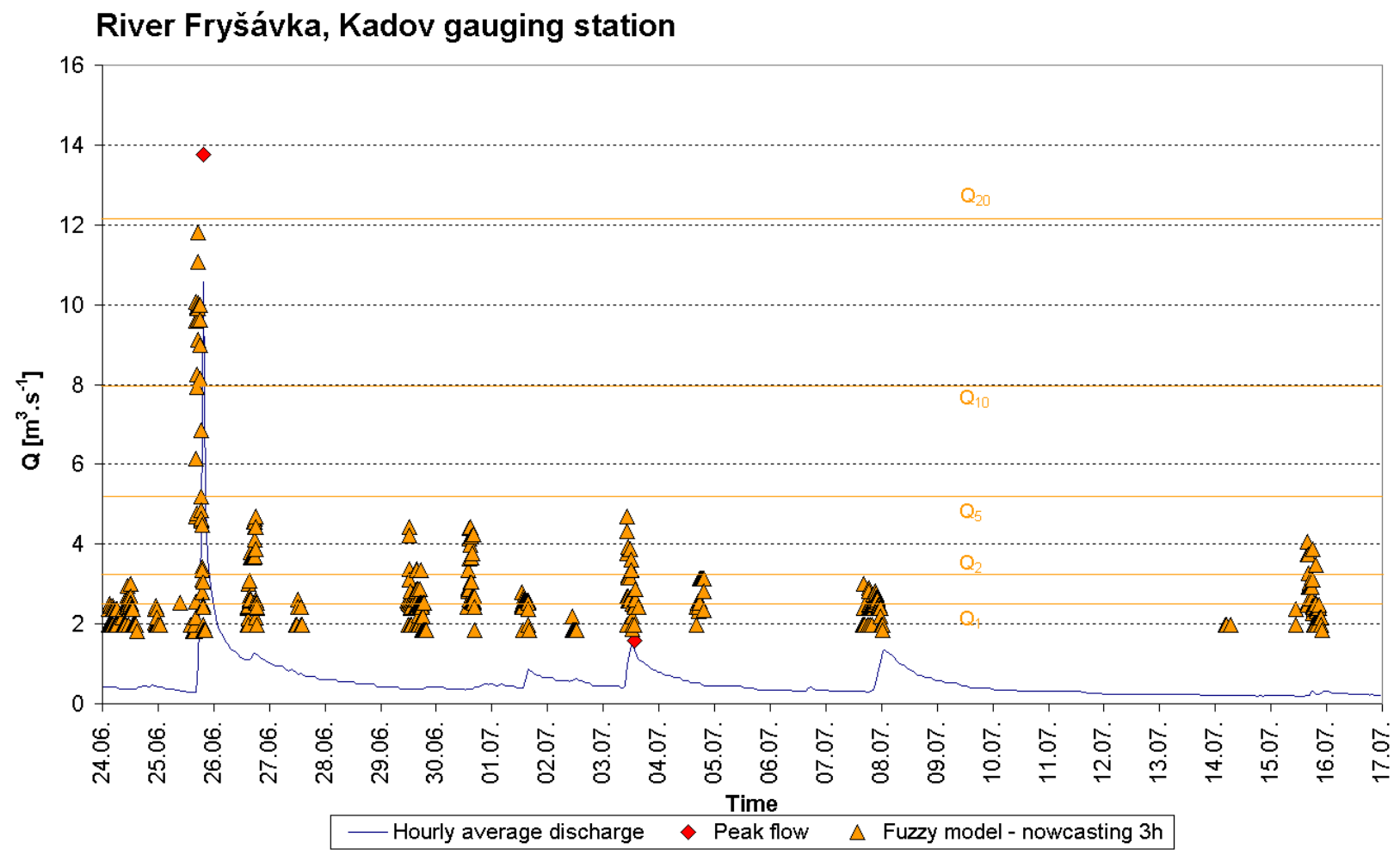

Fig. 10. Peak flow estimates - Fryšávka River basin - precipitation nowcasting (3h). 


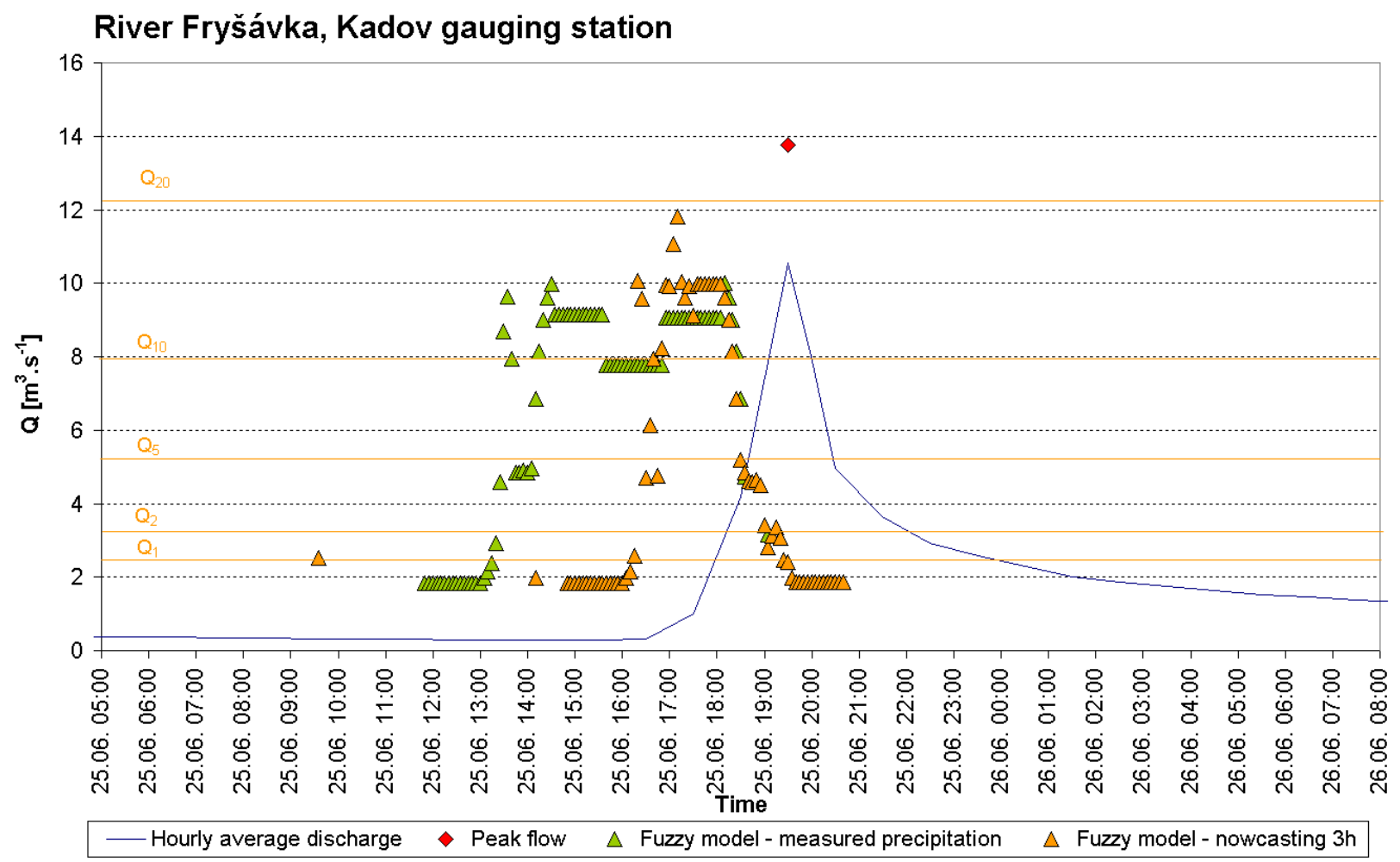

Fig. 11. Peak flow estimates - Fryšávka River basin - comparison of results based on measured precipitation only and results based on precipitation nowcasting (3h) - the flood event of 25. 6. 2009.

values may be significantly changeable over the short term, especially values at the end of the forecast validity time. As a reaction to this changeability, estimated peak flows may reach high values in isolated cases. That is why peak flow estimates have to exceed the selected limit of $Q_{2}$ in at least three calculation steps before they are considered an alarm signal from the model. In the case of a successful forecast it was investigated as to whether the estimated peak flows reached the same return period of discharge value as in reality. E.g. if the real peak flow was between the 5-year and 10-year discharge value, the peak flow estimates under $Q_{5}$ were considered as having been underestimated and estimates over $Q_{10}$ were considered as having been overestimated.

The evaluation method was strictly adhered to in all cases, even if the result of the evaluation can be debatable in some situations.

Within the 73 evaluated basins, 29 flood events with a peak flow of over $Q_{2}$ occurred during the period of simulation. In cases when 3 hour precipitation nowcasting was replaced by measured values, the fuzzy model successfully forecasted the exceeding of $Q_{2}$ in 20 cases (according to the above-mentioned evaluation method). During 9 flood events the model forecast failed and the total number of false alarms was 31 . Within the group of successful forecasts the peak flow estimates exceeded the same return period of discharge value as real peak flows did in 10 cases. In the remaining 10 cases the forecasts were underestimated.

Using data obtainable in real time (3 hour precipitation nowcasting) the model was, as regards prediction of the exceeding of $Q_{2}$, as successful as in cases where nowcasted precipitation was replaced by measurements (20 successful forecasts and 9 failed forecasts). However, the number of false alarms increased significantly when real-time data was used: to be specific, 121 false alarms occurred. Within the group of successful forecasts the peak flow estimates exceeded the same return period of discharge value as the real peak flows in 8 cases. In 10 cases the forecasts were underestimated and in 2 cases they were overestimated. Simulations were also performed using only 1 hour precipitation nowcasting. They were only performed for a few selected basins, which is why their results were not included in the general evaluation. However, the results show that using shorter precipitation nowcasting evokes a significant reduction in false alarms. Shorter precipitation nowcasting means shorter maximal potential earliness of forecasting; however, the input data are more precise. 


\section{Summary}

Pattern data quality (the representativeness of the pattern matrix) has the most significant effect on the quality of the assembled fuzzy model, whether the model is intended for flash flood prediction or for another purpose. It is required that the input data (points in multidimensional input-output space) cover the input-output space uniformly. This requirement is fundamental and is more important than the number of patterns available in the pattern matrix. An excess of points in a certain area of input-output space generally implies the noising of the solution. A lack of points in a certain area of input-output space generally implies problems with the approximation of the relations in a given area of input-output space. The resulting fuzzy model was assembled on the basis of a pattern matrix which has a small number of rows (patterns). Due to the data acquired during the numerous flash floods in the summer of 2009 , the pattern matrix significantly expanded. During future operation of the model, the pattern matrix will become more and more representative as the number of rows increase, which will improve the results gained from the model. It may be assumed that the data obtained during future operation of the model will be of higher quality than the historical data used for current model configuration.

The success of precipitation forecasts is fundamental for the hydrological forecasts that follow, as the results confirm. Using precipitation nowcasting (data obtainable in real time), the forecasts of the model were marked by a higher number of false alarms. The usage of 3 hour precipitation nowcasting results in the peak flow estimates of the fuzzy model being adversely influenced by forecasted rainfall intensities at the end of the nowcasting lead time (the last 1 hour). When 1 hour precipitation nowcasting was used instead of 3 hours, the number of false alarms notably decreased. The lead time of the fuzzy model forecast was not significantly shortened during the simulation of model operation with 1 hour precipitation nowcasting. However, in cases when precipitation forecasts were precise the use of 1 hour (instead of 3 hour) nowcasting would lead to the loss of the theoretical opportunity of obtaining longer flood warning lead times. A reasonable compromise appears to be the usage of 2 hour precipitation nowcasting.

Although continuous development is taking place in the field of meteorological radar measurement, it still only provides an estimate of real rain- fall. In the case of very small basins, there is a problem with the spatial location of rainfall by meteorological radar. In the case of larger basins, there is a problem with the usage of average rainfall intensity over the area of the basin. In most cases when flooding occurred and the fuzzy model failed to forecast higher peak flow the cause could be found in the input values characterizing the causal rainfall. In these cases the rainfall intensity values did not reach levels which in usual situations produce flooding in the given basins. It is necessary to differentiate between the accuracy of forecasts as such and the accuracy of fuzzy models. The total accuracy of forecasts consists of precipitation forecast accuracy and the accuracy of hydrological forecasting using fuzzy model.

The development of flash flood prediction tools is desirable, as the consequences of flash floods in recent years show. Classical forecasting methods fail in the case of flash floods because of the complexity of the problem and the great deal of uncertainty involved. The relations between the causal rainfall, factors affecting the rainfall-runoff process and the resulting outflow from a small river basin are hard to describe accurately. Moreover, it is necessary to work with very uncertain input data. The configuration of fuzzy models is derived directly from measured data and makes it possible to find hidden relations in this data even in conditions of significant uncertainty.

Although the fuzzy model used in this study was configured on the basis of a relatively small number of pattern situations within a relatively small set of pattern basins, it achieved quite good results even within the relatively large set of modeled basins. The model utilized the experience gained from pattern basins also for basins not included in the pattern matrix. Flash floods are often labeled as being unpredictable events. The presented results show that the flash flood forecasting problem is in some way solvable.

Causal rainfall is characterized by both the intensity and the duration of rain. This allows a fuzzy model to differentiate between rainfalls with the same total precipitation but which behave differently over time. The lower accuracy of outputs and the reduction of forecasting to a mere estimation of peak flow are compensated by the very high calculation speed and the opportunity to use the latest meteorological data. The operation of the model was only simulated for a short time, even if a lot of flash floods occurred during the simulated time period; the season-long operation of the model will 
provide a more complex insight into model behavior and the next possibilities for model development.

During further development to improve the results of the fuzzy forecasting model it is intended that the current input variables will be adjusted and that consideration will be given to the addition of new input variables. Currently, the calculation of API is derived from daily precipitation totals calculated up until $6 \mathrm{AM}$. It is intended that 24 hour running totals will be used instead. The API input variable will also take into account the time period between $6 \mathrm{PM}$ and the causal rainfall, which is not covered currently.

The inclusion of input uncertainties is another step in the further development of the fuzzy model. The most significant uncertainties concern inputs characterizing causal rainfall. In view of the high calculation speed of the fuzzy model there is an opportunity to use an ensemble of precipitation forecasts at each step of the calculation. The output of the model will then be a set of estimated peak flows for each modeled basin. This set will be statistically processed.

Cooperation with the Czech Hydrometeorological Institute was very helpful for the development of the fuzzy model discussed in this article. The institute possesses facilities needed for both the configuration of the model and its operation. Hydrological forecasts follow on from and are related to meteorological forecasts. The success of a hydrological model, however sophisticated it is, will always depend on the quality of input data. The cooperation of specialists from both branches is necessary for the effective solution of the flash flood forecasting problem. Hydrologists have to lay out their demands regarding the form precipitation forecasting should take, and they have to try to utilize all the facilities which current meteorology is able to provide.

This article was written as a part of the GA ČR project: 103/07/1620 "Prediction and simulation models in the water resources control".

\section{REFERENCES}

JANÁL P., STARÝ M., 2009a: Fuzzy model pro předpověd' stupně ohroženosti povodí povodněmi z př́valových dešt’u. (Fuzzy model use for prediction of the state of emergency of river basin in the case of flash flood.) J. Hydrol. Hydromech., Vol. 57, No. 3, p. 145-153.

JANÁL P., STARÝ M., 2009b: Fuzzy Model Use for Evaluation of Peak Outflow from River Basin during Flash Flood, CCWI, p. 725-729, Sheffield, ISBN 978-0-415-54854-9.

JANÁL P., STARÝ M., 2010: Operativní předpovědi povodní z prrívalových deštů pomocí fuzzy modelu. Hydrologické dny 2010, Hradec Králové, 5 s., CHMI, Prague, ISBN 97880-86690-84-1.

JANG J. R., 1993: ANFIS: Adaptive-Network-Based Fuzzy Inference System. IEEE Transactions on Systems, Man, and Cybernetics, Vol. 23, No. 3, 1993.

MATLAB + Fuzzy Logic Toolbox + Neuro Toolbox, The Language of Technical Computing, The MathWorks, 1984$-2012$.

NACHÁZEL K., STARÝ M., ZEZULÁK J., 2004: Využití metod umělé inteligence ve vodním hospodářství. Academia, Prague, ISBN 80-200-02229-4.

NOVÁK V., 1990: Fuzzy množiny a jejich aplikace. SNTL, Prague.

SZOLGAY J., DZUBÁK M., HLAVČOVÁ K., 1994: Hydrológia - Odtokový proces a hydrológia povrchových vôd. Vydavatel'stvo STU, Bratislava. ISBN 80-227-0641-8.

TRUPL J., 1958: Intensity krátkodobých dešt’ů v povodích Labe, Odry a Moravy. VÚV, Prague.

Received 17 February 2012 Accepted 19 June 2012 